\title{
THE VERSE PROBLEMS OF EARLY AMERICAN ARITHMETICS
}

\author{
BY HAROLD DON ALLEN
}

Mr. Allen is a student in the Department of Curriculum and

Instruction of the Rutgers Graduate School of Education

\author{
$A, B$, and $C$, met at an inn, \\ Where they grew very merry \\ With drinking brandy, wine, and gin, \\ Some glasses too of cherry ...
}

7 HE one-volume school Arithmetics published in the United States prior to about I 850 are characterized by an evident

1 seriousness of purpose and space-conscious avoidance of verbalization. Without illustrations, packed with rules and examples, their crowded pages attempt to extend knowledge and skills from counting and number combinations to the most advanced of algorithms and applications. One would hardly expect, in such circumstances, a high level of human interest, or even a considered diversity of approach. The last thing to be anticipated would be light verse!

That the old Arithmetics include so much clearly intended to be of contemporary interest and relevance, and from our vantage point possessing nostalgic or antiquarian charm, is to the credit of the several generations of writers and compilers, a little-known group of dedicated workers whose imagination, resourcefulness, even humor, is preserved in the problems they conceived and perpetuated. Questions illustrating Single Fellowship; Double Position; the Rules of Three, Five, and Seven; Compound Proportion Inverse; Alligation; Tare and Trett; and other phases of traditional school arithmetic, show effort, not unsuccessful, to make the subject interesting, significant, or perhaps both. The poems, in the form of which, on occasion, problems were stated, are something of a category unto themselves. Consider an early example, from Workman's The American Accountant (Philadelphia, I 789): :

${ }^{1}$ Benjamin Workman, The American Accountant, or Schoolmaster's New Assistant 
Ia.

When first the marriage knot was tied

Betwixt my wife and me,

My age did hers as far exceed,

As three times three do three;

But after ten and half ten years,

We man and wife had been,

Her age came up as near to mine,

As eight is to sixteen.

Now Tyro skill'd in numbers, say

What were our ages on the wedding day?

To which the answer, a rhyming couplet, is:

Sir, forty-five years you had been,

Your bride no more than just fifteen.

The verse, which may not be original with Workman, can be shown to have reappeared, in various versions, over the following six decades. Zachariah Jess, "schoolmaster in Wilmington," incorporates it in his The American Tutor's Assistant, editions of I799, I8I I, and I $821 .^{2}$ It then finds a place in Titus Bennett's The New System of Practical Arithmetic, I 824 and $\mathrm{I} 834 .{ }^{3}$ The verse appears in its final form in M'Cord's revision of Willett's Mental and Practical Arithmetic, 1849, the last Arithmetic known to have included verse problems, and the wording is as follows: ${ }^{4}$

\section{$I b$.}

When first the marriage knot was tied

Between my wife and me,

My age was to that of my bride

As three times three to three;

But now, when ten and half ten years

We man and wife have been,

Her age to mine exactly bears

As eight is to sixteen:

(Philadelphia, I789), 209. Materials in several Rutgers Library collections have been freely consulted in the preparation of the manuscript. United States textbooks published prior to 1820 are in the Rare Book Collection. Later editions, with school texts of the I $820-1900$ period, are separately housed.

2 Zachariah Jess, The American Tutor's Assistant, Improved (Wilmington, 1799), i 94.

3 Titus Bennett, Revised Impression of the New System of Practical Arithmetic (rst standing ed.; Philadelphia, i 824 ), 178 .

${ }^{4}$ Augustus R. M'Cord, Willett's Mental and Practical Arithmetic (and ed.; Poughkeepsie, I 849 ), 305 . 
Now tell, I pray, from what I've said, What were our ages when we wed?

The problem, essentially one in Double Position, is given its answer again in verse:

Thy age, when married, must have been

Just forty-five; thy wife's fifteen.

Changes in wording are seen to have improved the statement of the problem, and to have eliminated awkward, perhaps obsolescent, phrasing.

Such verse problems appear in some of the earliest American Arithmetics. The two posthumous editions of Dilworth's The Schoolmasters Assistant (Philadelphia, I78I) provide these illustrations, both reprinted, with minor changes, in Phineas Merrill's The Scholar's Guide to Arithmetic, I 793."

II.

If one Pound ten and forty Groats

Will buy a Load of Hay;

How many Pounds with nineteen Crowns

For twenty Loads will pay?

(The answer, $38 \mathrm{k}$. I I s. $8 \mathrm{~d}$., follows from knowledge that "one Pound ten" is thirty shillings, each of twelve pence, while the groat is an obsolete silver four pence and the Crown a traditional five shillings.)

\section{III.}

A Gentleman a Chaise did buy, An Horse and Harness too;

They cost the Sum of threescore Pounds, Upon my Word 'tis true;

The Harness came to half th' Horse,

The Horse twice of the Chaise;

And if you find the Price of them,

Take them and go your Ways.

A good instance of a recurring problem is one calling for deter-

${ }^{5}$ In terms of number of editions, Dilworth, an English author, had produced "the most popular of the early arithmetics published in America" [Karpinski]. Thomas Dilworth, The Schoolmasters Assistant (Philadelphia: Joseph Crukshank, I78 I), 177, I 79; (Philadelphia: R. Aitken, I78I), 204, 207; Phineas Merrill, The Scholar's Guide to Arithmetic (Exeter, 1793), 96 . 
mination of the radius of a circle to enclose an acre. The question, in prose form, is found in most nineteenth-century Arithmetics. Bonnycastle, the English author, provides a poem in the I 823 Philadelphia edition of his Mensuration: ${ }^{6}$

\section{IVa.}

In the midst of a meadow well stored with grass,

I took just an acre to tether my ass;

How long must the cord be, that feeding all round,

He may'nt graze less or more than an acre of ground?

M'Cord, publishing in I 849 , submits this version:

\section{$I V b$.}

A horse in the midst of a meadow suppose,

Made fast to a stake by a line from his nose:

How long must the line be, that feeding all round,

Permits him to graze just an acre of ground?

Bonnycastle, with nineteenth-century unconcern for reasonableness of precision, gives the length as 39.25073 yards; M'Cord as I I $7 \mathrm{ft}$. $9+$ in.

An eight-line verse embodying the familiar "hare and hounds" rate problem is found in at least three Arithmetics. This version may be original with Bennett (I824). It is found unaltered in M'Cord ( I 849).

$V$.

As I was beating on the forest grounds,

Up starts a hare before my two grayhounds;

The dogs, being light of foot, did fairly run

Unto her fifteen rods just twenty-one.

The distance that she started up before

Was fourscore sixteen rods just, and no more:

Now this I'd have you unto me declare,

How far they ran before they caught the hare?

Tobias Ostrander, in The Elements of Numbers, or Easy Instructor ( I 823) offers a somewhat different version." "The miscellaneous

${ }^{6} \mathrm{John}$ Bonnycastle, An Introduction to Mensuration and Geometry (3rd American ed.; Philadelphia, 1 823), 230.

7 Tobias Ostrander, The Elements of Numbers, or Easy Instructor (2nd ed.; Canandaigua, 1823), 82. Of Ostrander, John Chapman, Teacher of Mathematics, acknowledges in a testimonial: "His miscellaneous matter contains a number of questions 
questions are calculated to amuse as well as instruct," Ostrander asserts. One hundred forty-eight lines of verse, some sixteen poems, find a place in his small book. The majority may have been his own work.

A number of verse questions, although by no means all, are fairly short. In his Schoolmaster's Assistant, Daboll asks:

$V I$.

If to my age there added be,

One-half, one-third, and three times three,

Six score and ten the sum will be;

What is my age, pray shew it me?

Of compound interest, Bonnycastle requires: ${ }^{9}$

VII.

If money be lent at three per cent.

To those who chuse to borrow,

In what time shall I be worth a pound,

If I lend a crown to-morrow?

Money quadruples, according to his answer, in 46.90036 years. Bonnycastle also poses a question on permutations:

\section{VIII.}

With guineas and moidores, the fewest, which way,

Three hundred and fifty-one pounds can I pay?

If paid every way 'twill admit of, what sum

Do the pieces amount to? - my fortune's to come.

While the question is unusual-guineas and moidores were, respectively, British and Portuguese gold pieces - it was not irrelevant to the United States. According to a contemporary Arithmetic (Emerson, I 839), both coins had been "rendered current by Act of Congress." They were, in a fully literal sense, "good as gold."10

calculated to divert, as well as afford exercise and instruction." The reference clearly is to the poems, found mainly among miscellaneous examples, pp. r90-204.

${ }^{8}$ Nathan Daboll, Daboll's Schoolmaster's Assistant (New-London, 1800), I76; 2nd ed. (New-London, I800), 202; and subsequent printings of $1821 ; 1828,1833,184 \mathrm{I}$, and $\mathrm{I} 843$.

9 John Bonnycastle, An Introduction to Algebra (7th ed.; London, 1805), 203, 206. A teacher at the Royal Military Academy, Woolwich, Bonnycastle was subsequently reprinted and apparently widely circulated in the United States.

${ }_{10}$ Frederick Emerson, The North American Arithmetic, Part Third (Boston, 1839), 246,248 . 
Ostrander offers this commercial illustration of the Rule of Three. Then, as now, the dime was, by law, the tenth of the dollar. The eagle was ten dollars, for I 30 years America's basic gold coin.

$I X a$.

Just fifteen pair of ladies' gloves

For sixty dimes had I;

How many pairs of that same kind

Will forty eagles buy?

An earlier version is due to Daboll:

$I X b$.

Just 16 yards of German serge,

For 90 dimes had I;

How many yards of that same cloth

Will I 4 eagles buy?

Also in a monetary vein, Ostrander asks:

$X$.

One hundred dollars you divide

Between two worthy men,

That when each part is fairly squar'd,

The difference is but ten [cents].

As revealed by the published answer, "The greatest part is $\$ 5005$ cts, the less $\$ 4995$," the difference is cents and the squaring allusion is more to "fair and square" than to the mathematical operation.

The couplet which follows, due to Ostrander, is surely the shortest of rhyming problems, and among the more difficult to interpret. A study in unorthodox proportion, its published answer is 120 :

$X I$.

If the third of eight be four,

What is the fifth of twenty score?

Only in the longer poems, however, can there be revealed the charm of this early problem form. Thus, in Bonnycastle's Mensuration, an arithmetical branch that would not have been expected to inspire poetry:

XII.

One ev'ning I chanc'd with a tinker to sit,

Whose tongue ran a great deal too fast for his wit: 
He talked of his art with abundance of mettle;

So I ask'd him to make me a flat-bottom'd kettle.

Let the top and the bottom diameters be,

In just such proportion as five is to three:

Twelve inches the depth I propos'd and no more;

And to hold in ale gallons seven less than a score.

He promis'd to do it and strait to work went;

But when he had done it he found it too scant.

He alter'd it then, but too big he had made it;

For though it held right the diameters fail'd it:

Thus making it often too big and too little,

The tinker at last had quite spoiled his kettle;

But he swears he will bring his said promise to pass,

Or else that he'll spoil every ounce of his brass.

Now to keep him from ruin, I pray find him out

The diameter's length, for he'll ne'er do't I doubt.

Neither the mensuration formula for the volume of the conic frustrum nor the capacity of the beer or ale gallon ( 282 cubic inches) is widely known among students of today, but the kettle dimensions do follow, I4.640I and 24.4002 inches.

Mahan's The Private Instructor, or Mathematics Simplified (Harrisburg, I 838) claimed to comprise "every thing necessary in arithmetic, bookkeeping, conveyancing, mensuration, and gauging, to form and complete the man of business."11 It included this one verse problem, readily following from an algebraic approach with two unknowns, but intended for arithmetic solution:

\section{$X I I I$.}

A father and his son upon a time,

Were laden with some bottles of French wine;

The son unto the father did complain,

That the weight of them his arms did sorely pain;

The father said, if one of yours I take,

My number double unto yours will make,

But if I one of mine to you do give,

As many as you have in all I still shall have-

How many bottles of this wine

Had each of them I pray define?

11 Jason M. Mahan, The Private Instructor, or Mathematics Simplified (Harrisburg, 1 838), 303 . 
M'Cord relates the following improbable social incident, which can give rise to an equation unusual in form:

\section{$X I V$.}

A country clown addressed a charming belle,

Who in both wit and learning did excel;

The youth, unskilled in numbers, as will show,

Desirous was the lady's age to know-

When she replied with a majestic air,

And piercing words peculiar to the fair,

"My age is such, if multiplied by three,

Two sevenths of that product tripled be,

The square root of two ninths of that is four:

Now tell my age, or never see me more."

Ostrander offers a somewhat similar tale, involving two sisters. The elder, ahead of her time, employed a standardized test in screening suitors. Solution of the basic problem can involve a pure quadratic, number theoretic insight, trial and error-or, one suspects, pure luck.

\section{$X V$.}

My sister's years are just to mine, As forty-six to sixty-nineAnd if you multiply them o'er, The product's six times sixty-four; Show thou our ages unto me, And I thy wedded wife will beAll other proffers are in vain, No other shall that favor gain.

Ostrander provides not only the largest, but also the most interesting, selection of verse problems. Consider this variation on the type-problem of the hare and hounds:

$X V I$.

A harmless dove was soaring high, To stretch her wings in space-

At length a hawk did her espy, And give the dove a chase;

Just forty chains were then between

Those birds as we could view-

When the poor dove flew seventeen,

The hawk just twenty-two; 
The hawk pursued with all its strength, As those who saw did say-

Then tell the chains he flew in length, Before he caught his prey?

Two questions introduce the heroes-occasionally villains-of eighteenth- and nineteenth-century Arithmetics, $A, B$, and $C$ :

\section{$X V I I$.}

$A, B$, and $C$, met at an inn,

Where they grew very merry

With drinking brandy, wine, and gin, Some glasses too of cherry;

At length the reck'ning they must pay,

To make all matters even-

$A$ paid two ninths, as poets say,

While $B$ and $C$ paid seven;

As oft as $B$ paid eighty cents,

$C$ paid the sum of fifty;

Now tell the cents each fellow spent,

If $C$ spent nine times twenty?

Answers, in cases such as this, may turn out to be unrealistic fractions. Nineteenth-century authors are undisturbed. $A$ paid "I,33 5/7 cts!”

\section{XVIII.}

If a fourth of your money you gave unto me,

Said $A$ with a smile to $B$ and to $C$,

With a thousand bright dollars I then should be bless'd,

'Twould pay off my debts and set me at rest;

Said $B$ to $A, C$, I plainly behold

If a fifth of your cash in my pocket were told,

The same sum of dollars my pocket would grace,

And a satisfied smile enliven my face:

If a sixth of your sums were added to mine,

Said $C$ to $B, A$, I would not repine,

For the same sum of dollars I then should behold,

Each time I approached my purse to unfold.

Ye lads who with learning and genius are bless'd,

Tell the number of dollars each man did possess-

With a heart full of friendship I'll give you my hand, And say that position you well understand. 
Ostrander offers, as well, an interesting variation on the "tinker" kettle mensuration problem, in eight lines:

\section{$X I X$.}

I agreed with a tinker, whose name was Dolittle,

To make for my wife a flat-bottomed kettle-

Twelve inches exactly the depth of the same,

And twenty-five gallons of beer to contain-

The number of inches across on the top

Was twice on the bottom when new at the shop;

How many inches across must the bottom then be,

Likewise on the top, pray shew unto me.

Top and bottom diameters, as given in the author's solution: 35.8096 and 17.9048 inches.

Flocks of sheep figure in two of Ostrander's easier problems, improbable questions which the arithmetically-inclined drover might be presumed to pose.

\section{$X X$}

Hail master! hail; two hundred sheep

You sure have in your drove;

Nay, said the owner, there is not

By forty and above-

But if you add one forth to them,

To make the number more,

And multiply the same by ten,

There will be fifty score.

How many sheep had he?

\section{$X X I$.}

Two drovers meeting on their way, And thus they said-“" 'Tis true,

If half your flock you give to me, I'll have just eighty-two."

"Nay, friend," the other soon replied,

"Add but a third to mine,

Of your best sheep-then I shall have

One hundred twenty-nine."

His answer was exactly true,

No scholar will impeach;

Then by your knowledge show to me

How many sheep had each? 
Ostrander will best be remembered, if history should accord him a place, for the particularly challenging problems, in verse form, that he set before American students. Here he touches on free fall, the simple pendulum, the visible horizon, and the more difficult topics in mensuration. Five illustrations serve to show the authorcompiler at his best. The first concerns an improvised rain gauge:

$X X I I$.

I plac'd a bowl into the storm, To catch the drops of rain-

A half a globe was just its form, Two feet across the same;

The storm was o'er, the tempest past, I to the bowl repair'd-

Six inches deep the water stood, It being measur'd fair;

Suppose a cylinder, whose base Two feet across within,

Had stood exactly in that place,

What would the depth have been?

The rainfall, according to Ostrander, was 2.5 inches.

An unusual problem, to which a moment's reflection may suggest several possible approaches to solution, is this-surely an early American variation on the traditional May pole:

\section{$X X I I I$.}

On the fourth of July a pole was erected, Composed of six pieces, and nicely connected;

Two feet and six inches it measured around,

On the place where it stood at the top of the ground;

The form was a cone in surface complete,

The height of the same was twice sixty feet;

What length of inch ribband procured at the shop,

Will wind round the pole from bottom to top,

And have it lay smooth and plain to be seen,

By leaving a space of five inches between?

The author gives, as answer, an exact Ioo yards.

An attractive problem, one calling for the height of a distant mountain viewed from the rigging of a ship, is the following. Reference, it would seem, is to Pico de Teide, highest peak in the Canary Islands, now taken to be I 2,162 feet. 
$X X I V$.

Just rising from the sea I've seen,

When station'd in the shrouds,

The lofty peak of Teneriffe,

That penetrates the clouds-

Just fifty leagues from it was I,

My reck'ning being true, And from the water to my eye,

The feet was eighty-two;

Suppose these observations just,

To make the question brief,

Above the level of the sea,

How high is Teneriffe?

Estimating Earth's diameter as 7,960 miles (still an acceptable approximation in such a problem), Ostrander obtains 2.4224 miles, i.e. 12,790 feet.

A question, initially appealing, which takes on added interest as it "opens up," is Ostrander's verse problem of round and square lots:

\section{$X X V$.}

A gentleman two daughters had, And both were very fair,

To each he gave a piece of land,

One round, the other square;

At forty eagles the acre, just,

Each piece its value had,

The dollars that encompassed each,

For each exactly paid;

If 'cross a dollar be an inch,

As it is very near,

Who had the better portion,

That had the round or square?

The side of the square and diameter of the circle turn out, significantly, to be equal. The value of the square piece of land is $\$ 62,726.40$, exactly, while that of the circular piece is of the order of $\$ 197,000$. The latter expression involves $p i$, and approximation becomes necessary. Ostrander, in giving his result to the ten millionth of a cent, ironically errs in the sixth decimal place of $p i$. His errata rectify the mistake, surely a minor classic of nonsignificant 
decimal places. The author, it is suspected, has further erred in twice counting the dollars at the corners of his square.

The allusion to a one-inch dollar suggests that the verse, or problem, may have been adapted from an earlier version, possibly one with shillings and guineas. Neither the gold nor silver dollar of the United States has in any sense approximated the inch.

Ostrander's remaining contribution to problem verse presupposes an acquaintance with schoolboy physics, or with variation as applied to physics. A gravitational question, it is simpler than it appears, for the result is independent of the gravitational constant, $g$. Ostrander misses this straightforward, somewhat elegant, approach.

\section{$X X V I$.}

I drop't a ball from Jackson's bridge, Its height above the stream to tell-

A pendulum two feet in length, Made six vibrations while it fell;

Can you in numbers fairly show How high this lofty bridge must be Above the stream that glides below, The feet and inches show to me?

The "correct" height, based on data provided in the poem, is $I 44^{2}$, roughly I 420 , feet. Ostrander gives 2 I 5 feet I0.54 inches. His error proves to be basic and major, an unusual happening in a nineteenth-century school Arithmetic. It stands out, once detected, in the interestingly antiquated "demonstration" (p. 204):

Demonstration: 39,2 inches the length of a pendulum, vibrating seconds; then 2 feet $X$ I $2=24$ inches the length of the pendulum; then 39,2$) 24=, 6 \mathbf{1} 22$ seconds the time of one vibration; then $, 6122 \times 6=3,6732$ seconds the time of the ball's descent; then $3,6732 \times$ $3,673^{2}=\mathrm{I} 3,49239824$; then $13,49239824 \times 16$ the number of feet that a ball or stone will fall in the time of one second $=215,87837184$ feet height of the bridge above the stream....

For several generations of American schoolboys, the verse problem is seen to have been a part, admittedly a small part, of arith- 
metic and related studies. The verse problem varied, in its depth and complexity, from merely the casual and interesting, to the difficult, challenging, and decidedly unusual. It now represents something of a lost art form! No American schoolmaster would seem to have posed a problem in verse in well over one hundred years. 